\title{
USABILITY SISTEM PENJAMINAN MUTU STIKOM BALI MENGGUNAKAN METODE USER CENTERED DESIGN
}

\author{
Ni Ketut Dewi Ari Jayanti \\ Program Studi Sistem Informasi \\ STMIK STIKOM Bali, Denpasar, Bali \\ daj@stikom-bali.ac.id
}

\begin{abstract}
The Quality Assurance Center (PJM) is one of the units at STMIK STIKOM Bali which has the task of assisting the Chair in overseeing and controlling the entire process. One of the controls carried out is controlling customer satisfaction through implementing customer satisfaction evaluations. PJM STIKOM Bali uses a web-based quality assurance information. The use of webbased quality assurance information systems has never been measured by usability system to see whether the system built is acceptability for the PJM STIKOM Bali unit in carrying out its activities. In this study, researchers conducted a study to analyze usability in the STIKOM Bali quality assurance information system. The method used to measure usability is User Centered Design $(U C D)$ because this method focuses on the user. In implementing the UCD method, three types of statements have been established, namely Task Complete Rate, Time on Task, and Usability Rate of System. The results achieved in this study were the success rates of respondents in completing the STIKOM Bali quality assurance information system task task of 97.67\%. The average time needed by respondents to complete all tasks is 92 minutes. The usability level felt by respondents when using the quality assurance information system is $88.75 \%$.
\end{abstract}

Keywords : Quality Assurance System, Usability, User Centered Design

\begin{abstract}
ABSTRAK
Pusat Jaminan Mutu (PJM) adalah salah satu unit di STMIK STIKOM Bali yang memiliki tugas membantu Ketua dalam mengawasi dan mengendalikan seluruh proses. Salah satu pengendalian yang dilakukan adalah pengendalian kepuasan pelanggan melalui pelaksanaan evaluasi kepuasan pelanggan. PJM STIKOM Bali menggunakan sistem informasi penjaminan mutu berbasis web untuk mempermudah akses penjadwalan dimulai dan diakhirinya proses evaluasi kepuasan pelanggan yang diintegrasikan dengan sistem lain yang ada di STIKOM Bali. Penggunaan sistem informasi penjaminan mutu berbasis web belum pernah dilakukan pengukuran usability sistem untuk melihat apakah sistem yang dibangun sudah akseptabilitas bagi unit PJM STIKOM Bali dalam melaksanakan aktivitasnya. Pada penelitian ini peneliti melakukan penelitian untuk menganalisa usability pada sistem informasi penjaminan mutu STIKOM Bali. Metode yang digunakan untuk mengukur usability adalah User Centered Design (UCD) karena metode ini berfokus pada pengguna. Dalam implementasi metode UCD, telah ditetapkan tiga jenis pernyataan yaitu Task Complete Rate, Time on Task, dan Usability Rate of System. Hasil yang dicapai pada penelitian ini adalah tingkat keberhasilan responden dalam menyelesaikan task sistem informasi penjaminan mutu STIKOM Bali sebesar 97,67\%. Waktu rata-rata yang diperlukan responden untuk menyelesaikan seluruh task adalah sebesar 92 menit. Tingkat usability yang dirasakan responden saat menggunakan sistem informasi penjaminan mutu adalah $88,75 \%$.
\end{abstract}

Kata kunci : Sistem Penjaminan Mutu, Usability, User Centered Design

\section{PENDAHULUAN}

STMIK STIKOM Bali merupakan salah satu perguruan tinggi swasta di Bali yang berfokus pada teknologi informasi. Salah satu unit di STMIK STIKOM Bali adalah Pusat
Jaminan Mutu (PJM) yang merupakan unsur pembantu pimpinan sebagai pelaksana pengawasan baik akademik maupun non akademik yang bertanggung jawab langsung kepada Ketua STMIK STIKOM Bali. Pusat Jaminan Mutu (PJM) memiliki tugas 
membantu Ketua STIKOM Bali dalam mengawasi dan mengendalikan seluruh kegiatan operasional Sekolah Tinggi yang berdasar pada standar yang ditetapkan. Bentuk pengawasan dan pengendalian yang dilakukan Pusat Jaminan Mutu (PJM) diantaranya pengawasan dan penanganan keluhan pelanggan, pengawasan proses melalui pelaksanaan audit, pengendalian seluruh dokumen sistem penjaminan mutu STIKOM Bali, serta pengendalian kepuasan pelanggan melalui pelaksanaan evaluasi kepuasan pelanggan.

Terkait dengan evaluasi kepuasan pelanggan, Pusat Jaminan Mutu (PJM) STIKOM Bali menggunakan suatu sistem informasi penjaminan mutu berbasis web untuk mempermudah akses penjadwalan dimulai dan diakhirinya proses evaluasi kepuasan pelanggan yang diintegrasikan dengan sistem lain yang ada di STIKOM Bali yaitu Elearning, Sistem Informasi Online (SION) dan Sistem Informasi Dosen (SID). Proses evaluasi kepuasan pelanggan dilakukan dengan penyebaran kuesioner melalui sistem informasi terintegrasi tersebut. Kendala yang selama ini muncul dalam pengembangan sistem informasi khususnya berbasis web adalah bagaimana membangun web yang tidak hanya memiliki pencitraan yang baik pada mesin pencari namun juga usability. Sistem informasi berbasis web yang berguna/ bermanfaat dibutuhkan karena dapat mempermudah kegiatan atau aktivitas yang dilakukan pengguna.

Pada penelitian sebelumnya dengan judul pengukuran usability sistem menggunakan use questionnaire pada aplikasi android, penelitian dilakukan dengan menggunakan kuesinoner sebagai instrumen penelitian dan menggunakan 5 kriteria usability yaitu learnability, efficiency, memorability, errors dan satisfaction. Tujuan dari penelitian ini adalah untuk menganalisis apakah aplikasi android memiliki akseptabilitas berdasarkan kriteria usability. Hasil penelitian menyatakan bahwa faktor yang paling dominan mempengaruhi tingkat kenaikan usability pada aplikasi android adalah mudah diingat (memorability) yang juga sekaligus berpengaruh positif dalam menaikkan tingkat akseptabilitas[1].

Pada penelitian lainnya dengan judul pengujian usability untuk meningkatkan antarmuka aplikasi mobile, penelitian ini menggunakan metode field observation yaitu dengan cara mengobservasi pengguna bagaimana mereka menggunakan aplikasi. Penelitian ini bertujuan untuk menentukan apakah sebuah aplikasi sudah sesuai dengan kebutuhan pengguna atau belum. Hasil dari penelitian ini menunjukkan bahwa metode observasi langsung dapat meningkatkan nilai usability dari $78.4 \%$ menjadi $91.1 \%$ sehingga aplikasi dapat sesuai dengan tujuan yaitu diterima oleh pengguna[2].

$\begin{gathered}\text { Penelitian lainnya dengan } \begin{array}{r}\text { judul } \\ \text { online }\end{array} \\ \text { rancangan lowongan }\end{gathered}$
menggunakan metode user centered design
studi kasus : business placement center
STMIK Amikom Yogyakarta. Penelitian ini
membahas mengenai pengelolaan website
alumni dalam memenuhi kebutuhan alumni
salah satunya memberikan informasi
mengenai lowongan pekerjaan. Hasil
penelitian mereka menunjukkan bahwa
pengguna merasa nyaman dengan tampilan
antarmuka website yang sudah dibangun,
informasi yang disajikan mudah dipahami
dan fitur-fitur menu sudah berhasil berjalan
sesuai fungsi [3].

Rosyidah, dkk pada penelitiannya yang berjudul evaluasi usability pada aplikasi Simpatika Direktorat Jenderal Pendidikan Islam Kementrian Agama, penelitian ini dilaksaakan dengan menyebar kuesioner dan melakukan wawancara kepada pengguna. Hasil yang diperoleh adalah usability pada aplikasi Simpatika memiliki persentase sebesar 71,54\%. Variabel yang paling signifikan berhubungan dengan aplikasi Simpatika adalah variabel efisiensi [4].

Pada unit Pusat Jaminan Mutu (PJM) STIKOM Bali, penggunaan sistem informasi penjaminan mutu berbasis web baru diimplementasikan selama 1 semester dan belum pernah dilakukan pengukuran usability sistem untuk melihat apakah sistem yang dibangun sudah akseptabilitas bagi unit Pusat Jaminan Mutu (PJM) STIKOM Bali dalam melaksanakan aktivitas atau kegiatannya khususnya dalam melaksanakan evaluasi kepuasan pelanggan.

Berdasarkan latar belakang tersebut, peneliti akan melakukan penelitian untuk mengukur usability pada sistem informasi penjaminan mutu STIKOM Bali dengan menggunakan metode User Centered Design (UCD). Pemilihan metode User Centered Design (UCD) pada penelitian ini karena 
metode ini berfokus pada pengguna dari suatu sistem informasi.

\section{METODE PENELITIAN}

Pengukuran usability sistem informasi penjaminan mutu STIKOM Bali menggunakan metode user centered design. Tahapan awal penelitian adalah identifikasi masalah yang dilanjutkan dengan studi pendahuluan, merancang alat ukur usability dengan metode User Centered Design (UCD), melaksanakan pengukuran usability, analisis pengukuran usability, evaluasi tingkat usability sebagai dasar dalam memberikan rekomendasi perbaikan sistem informasi penjaminan mutu STIKOM Bali.

Kajian tentang usability (kegunaan) merupakan bagian dari bidang ilmu multi disiplin Human Computer Interaction (HCI). Human Computer Interaction merupakan bidang ilmu yang berkembang sejak tahun 1970 yang mempelajari bagaimana mendesain tampilan layar komputer dalam suatu aplikasi sistem informasi agar nyaman dipergunakan oleh pengguna. Usability berasal dari kata Usable yang secara umum berarti dapat digunakan dengan baik. Sesuatu dapat dikatakan berguna dengan baik apalagi kegagalan dalam penggunaanya dapat dihilangkan atau diminimalkan serta memberi manfaat dan kepuasan kepada pengguna [5].

Usability mengacu kepada bagaimana pengguna bisa mempelajari dan menggunakan produk untuk memperoleh tujuannya dan seberapa puaskah mereka terhadap penggunannya. Definisi usability lainnya adalah sejauh mana suatu produk dapat digunakan oleh pengguna tertentu untuk mencapai target yang ditetapkan dengan efektivitas, efesiensi dan mencapai kepuasan penggunaan dalam konteks tertentu. Konteks penggunaan terdiri dari pengguna, tugas, peralatan (hardware, software dan material). Berdasarkan definisi tersebut usability diukur berdasarkan komponen [6]:

a. Kemudahan (learnability) didefinisikan seberapa cepat pengguna mahir dalam menggunakan sistem serta kemudahan dalam penggunaan menjalankan suatu fungsi serta apa yang pengguna inginkan dapat meraka dapatkan.

b. Efisiensi (efficiency) didefenisikan sebagai sumber daya yang dikeluarkan guna mencapai ketepatan dan kelengkapan tujuan. c. Mudah diingat (memorability) didefinisikan bagaimana kemapuan pengguna mempertahankan pengetahuannya setelah jangka waktu tertentu, kemampuan mengngat didapatkan dari peletakkan menu yang selalu tetap.

d. Kesalahan dan keamanan (errors) didefinisikan berapa banyak kesalahankesalahan apa saja yang dibuat pengguna, kesalahan yang dibuat pengguna mencangkup ketidaksesuaian apa yang pengguna pikirkan dengan apa yang sebenarnya disajikan oleh sistem.

e. Kepuasan (satisfaction) didefinisikan kebebasan dari ketidaknyamanan, dan sikap positif terhadap penggunaan produk atau ukuran subjektif sebagaimana pengguna merasa tentang penggunaan sistem.

User Centered Design (UCD) adalah proses desain yang berfokus pada kebutuhan pengguna. Produk yang dikembangkan dengan pendekatan User Centered Design (UCD), dioptimalkan untuk end-user serta ditekankan pada bagaimana kebutuhan atau keinginan end-user terhadap penggunaan suatu produk. Desain dirancang dengan adaptasi terhadap behavior atau perilaku pengguna dalam menggunakan produk sehingga produk yang dikembangkan tidak memaksa pengguna untuk mengubah perilakunya ketika menggunakan produk tersebut. Tujuannya adalah agar produk yang dikembangkan dapat bermanfaat serta mudah digunakan bagi pengguna[7].

Dalam User Centered Design (UCD) baik kebutuhan, keinginan, dan keterbatasan end user dari suatu produk mendapat perhatian yang mendalam. User Centered Design (UCD) dapat ditandai sebagai sebuah problem solving yang tidak hanya membutuhkan para perancang untuk menganalisa dan meramalkan bagaimana para pengguna cenderung menggunakan produk tetapi juga menguji validitas asumsi mereka melalui evaluasi terhadap prilaku user dalam kehidupan nyata dan terhadap user yang sebenarnya. Evaluasi ini diperlukan untuk mengetahui kebutuhan user karena sangat sulit memahami desain yang diinginkan user berdasarkan pengalamannya dalam menggunakan produk yang pernah dipakai sebelumnya [7]

Tujuan dari User Centered Design (UCD) menurut adalah untuk menghasilkan produk 
yang memiliki tingkat usability yang tinggi. Hasil menggunakan User Centered Design (UCD) untuk desain sistem adalah produk yang menawarkan pengalaman yang lebih efisien, memuaskan, dan usability untuk pengguna, yang kemungkinan akan meningkatkan penjualan dan loyalitas pelanggan. Untuk memaksimalkan User Centered Design (UCD) dalam mengevaluasi tingkat usability produk maka dibutuhkan data-data yang dihasilkan pengguna produk pada saat evaluasi. Data-data yang dimaksud adalah data performasi, data preferensi dan data mengenai skala rating usability[7].

a. Data performasi, yaitu data yang menyatakan apa yang sebenarnya terjadi ketika pengguna menggunakan situs.

b. Data preferensi, yaitu data yang menyatakan apa yang dipikirkan oleh pengguna ketika sedang melakukan atau ketika selesai menggunakan situs.

c. Data skala rating usability, yaitu data yang menyatakan tentang tingkat kepuasan yang dirasakan pengguna setelah menggunakan produk.

Data performasi didapatkan melalui pengukuran terhadap tingkat kegagalan user dalam menyelesaikan task dari suatu fungsi. Task yang dimaksud adalah event - event yang dilakukan pengguna selama menggunakan fungsi sistem. Semakin banyak tingkat kegagalan pengguna dalam menyelesaikan task dalam suatu fungsi maka semakin besar peluang fungsi tersebut harus diperbaiki.

Data preferensi didapatkan melalui pengukuran terhadap waktu yang dibutuhkan seorang pengguna dalam menyelesaikan setiap task dalam fungsi tersebut. Semakin lama waktu yang dibutuhkan seorang pengguna dalam menyelesaikan sebuah task maka semakin besar peluang task tersebut harus diperbaiki. Sebab kemungkinan yang menyebabkan waktu yang diperlukan pengguna untuk menyelesaikan task menjadi lama adalah akibat dari kerumitan penggunaan fungsi itu sendiri.

Data skala rating usability didapatkan dengan menterjemahkan poin usability itu sendiri kedalam pertanyaan-pertanyaan kuesioner. Poin usability yang dimaksud adalah usability dari fungsi tersebut secara global, tidak mengkhusus pada task yang ada dalam fungsi yang dievaluasi.
Penelitian ini merupakan penelitian lanjutan dari penelitian yang sebelumnya yang berjudul "Analisis Usability Sistem Penjaminan Mutu STIKOM Bali menggunakan Metode User Centered Design". Hasil yang dicapai pada penelitian ini adalah hasil analisa usability sistem informasi penjaminan mutu STIKOM Bali menggunakan metode User Centered Design (UCD) dengan menetapkan tiga jenis pernyataan yaitu Task Complete Rate, Time on Task, dan Usability Rate of System. [8]

Penerapan metode User Centered Design (UCD) terhadap sistem penjaminan mutu STIKOM Bali dilakukan dengan bantuan kuesioner. Oleh karena itu dalam perancangan kuesioner harus berdasar pada aspek kebutuhan akan kenyamanan pengguna terhadap sistem. Untuk mencapai aspek tersebut maka perancangan setiap pernyataan yang akan dinyatakan dalam kuesioner harus dianalisa terlebih dahulu.

Proses analisa kuesioner dilakukan dengan melakukan perbandingan pertanyaan yang sesuai dengan task yang akan diuji dan User Centered Design (UCD) itu sendiri. Untuk lebih memudahkan penyusunan pernyataan, maka pernyataan-pernyataan tersebut di fokuskan pada fungsi/ feature yang ada didalam sistem informasi penjaminan mutu STIKOM Bali. Setelah menetapkan pernyataan, maka bobot untuk setiap pernyataan pun ditetapkan.

Dalam implementasi metode User Centered Design (UCD) pada sistem informasi penjaminan mutu STIKOM Bali terdapat tiga jenis pernyataan. Setiap pernyataan memiliki tujuan yang berbeda beda dalam menggambarkan tingkat kenyamanan pengguna sistem terhadap sistem yang mereka gunakan. Ketiga jenis pernyataan itu meliputi [8]:

1. Task Complete Rates, adalah jenis pernyataan yang bertujuan mengukur tingkat keberhasilan responden dalam menyelesaikan task sistem. Pernyataan task complete rates dapat dilihat pada Tabel 1 .

2. Time on Task, adalah jenis pernyataan yang bertujuan mengukur waktu yang diperlukan responden untuk menyelesaikan suatu task dalam sistem tersebut. Pernyataan time on task dapat dilihat pada Tabel 2.

3. Usability Rate of System, adalah jenis pernyataan yang bertujuan untuk mengukur tingkat kenyamanan yang dirasakan responden saat menggunakan 
sistem. Pernyataan usability rate of system dapat dilihat pada Tabel 3.

Tabel 1. Pernyataan Task Complete Rates

\begin{tabular}{|c|c|c|c|}
\hline \multirow[t]{2}{*}{ Task \# } & \multirow[t]{2}{*}{ Pernyataan } & \multicolumn{2}{|c|}{ Nilai Jawaban } \\
\hline & & Ya & Tidak \\
\hline Task 1 & Apakah anda berhasil menyelesaikan proses login? & 1 & 0 \\
\hline Task 2 & Pada fungsi kuesioner, sub fungsi PBM, apakah anda berhasil input keterangan ? & 1 & 0 \\
\hline Task 3 & Pada fungsi kuesioner, sub fungsi PBM, apakah anda berhasil input skala likert? & 1 & 0 \\
\hline Task 4 & Pada fungsi kuesioner, sub fungsi PBM, apakah anda berhasil input tahun ajaran ? & 1 & 0 \\
\hline Task 5 & Pada fungsi kuesioner, sub fungsi PBM, apakah anda berhasil pilih semester ? & 1 & 0 \\
\hline Task 6 & Pada fungsi kuesioner, sub fungsi PBM, apakah anda berhasil input date range? & 1 & 0 \\
\hline Task 7 & $\begin{array}{l}\text { Pada fungsi kuesioner, sub fungsi PBM, apakah anda berhasil mengaktivasi tombol } \\
\text { SION? }\end{array}$ & 1 & 0 \\
\hline Task 8 & $\begin{array}{l}\text { Pada fungsi kuesioner, sub fungsi PBM, apakah anda berhasil mengaktivasi tombol } \\
\text { elearning? }\end{array}$ & 1 & 0 \\
\hline Task 9 & $\begin{array}{l}\text { Pada fungsi kuesioner, sub fungsi PBM, apakah anda berhasil mengaktivasi tombol } \\
\text { open? }\end{array}$ & 1 & 0 \\
\hline Task 10 & $\begin{array}{l}\text { Pada fungsi kuesioner, sub fungsi PBM, apakah anda berhasil unduh template } \\
\text { pengisian PBM? }\end{array}$ & 1 & 0 \\
\hline Task 11 & Pada fungsi kuesioner, sub fungsi PBM, apakah anda berhasil tambah soal ? & 1 & 0 \\
\hline Task 12 & Pada fungsi kuesioner, sub fungsi PBM, apakah anda berhasil import data ? & 1 & 0 \\
\hline Task 13 & Pada fungsi kuesioner, sub fungsi PBM, apakah anda berhasil simpan data ? & 1 & 0 \\
\hline Task 14 & $\begin{array}{l}\text { Pada fungsi kuesioner, sub fungsi kepuasan mahasiswa, apakah anda berhasil input } \\
\text { keterangan? }\end{array}$ & 1 & 0 \\
\hline Task 15 & $\begin{array}{l}\text { Pada fungsi kuesioner, sub fungsi kepuasan mahasiswa, apakah anda berhasil input } \\
\text { skala likert? }\end{array}$ & 1 & 0 \\
\hline Task 16 & $\begin{array}{l}\text { Pada fungsi kuesioner, sub fungsi kepuasan mahasiswa, apakah anda berhasil input } \\
\text { tahun ajaran? }\end{array}$ & 1 & 0 \\
\hline Task 17 & $\begin{array}{l}\text { Pada fungsi kuesioner, sub fungsi kepuasan mahasiswa, apakah anda berhasil pilih } \\
\text { semester? }\end{array}$ & 1 & 0 \\
\hline Task 18 & $\begin{array}{l}\text { Pada fungsi kuesioner, sub fungsi kepuasan mahasiswa, apakah anda berhasil input } \\
\text { date range? }\end{array}$ & 1 & 0 \\
\hline Task 19 & $\begin{array}{l}\text { Pada fungsi kuesioner, sub fungsi kepuasan mahasiswa, apakah anda berhasil } \\
\text { mengaktivasi tombol SION? }\end{array}$ & 1 & 0 \\
\hline Task 20 & $\begin{array}{l}\text { Pada fungsi kuesioner, sub fungsi kepuasan mahasiswa, apakah anda berhasil } \\
\text { mengaktivasi tombol elearning? }\end{array}$ & 1 & 0 \\
\hline Task 21 & $\begin{array}{l}\text { Pada fungsi kuesioner, sub fungsi kepuasan mahasiswa, apakah anda berhasil } \\
\text { mengaktivasi tombol open ? }\end{array}$ & 1 & 0 \\
\hline Task 22 & $\begin{array}{l}\text { Pada fungsi kuesioner, sub fungsi kepuasan mahasiswa, apakah anda berhasil unduh } \\
\text { template pengisian kepuasan mahasiswa? }\end{array}$ & 1 & 0 \\
\hline Task 23 & $\begin{array}{l}\text { Pada fungsi kuesioner, sub fungsi kepuasan mahasiswa, apakah anda berhasil tambah } \\
\text { soal ? }\end{array}$ & 1 & 0 \\
\hline Task 24 & $\begin{array}{l}\text { Pada fungsi kuesioner, sub fungsi kepuasan mahasiswa, apakah anda berhasil import } \\
\text { data? }\end{array}$ & 1 & 0 \\
\hline Task 25 & $\begin{array}{l}\text { Pada fungsi kuesioner, sub fungsi kepuasan mahasiswa, apakah anda berhasil simpan } \\
\text { data ? }\end{array}$ & 1 & 0 \\
\hline Task 26 & $\begin{array}{l}\text { Pada fungsi kuesioner, sub fungsi kepuasan dosen, apakah anda berhasil input } \\
\text { keterangan? }\end{array}$ & 1 & 0 \\
\hline Task 27 & $\begin{array}{l}\text { Pada fungsi kuesioner, sub fungsi kepuasan dosen, apakah anda berhasil input skala } \\
\text { likert? }\end{array}$ & 1 & 0 \\
\hline Task 28 & $\begin{array}{l}\text { Pada fungsi kuesioner, sub fungsi kepuasan dosen, apakah anda berhasil input tahun } \\
\text { ajaran ? }\end{array}$ & 1 & 0 \\
\hline Task 29 & $\begin{array}{l}\text { Pada fungsi kuesioner, sub fungsi kepuasan dosen, apakah anda berhasil pilih } \\
\text { semester? }\end{array}$ & 1 & 0 \\
\hline Task 30 & $\begin{array}{l}\text { Pada fungsi kuesioner, sub fungsi kepuasan dosen, apakah anda berhasil input date } \\
\text { range? }\end{array}$ & 1 & 0 \\
\hline Task 31 & $\begin{array}{l}\text { Pada fungsi kuesioner, sub fungsi kepuasan dosen, apakah anda berhasil } \\
\text { mengaktivasi tombol SID ? }\end{array}$ & 1 & 0 \\
\hline Task 32 & $\begin{array}{l}\text { Pada fungsi kuesioner, sub fungsi kepuasan dosen, apakah anda berhasil } \\
\text { mengaktivasi tombol elearning? }\end{array}$ & 1 & 0 \\
\hline Task 33 & $\begin{array}{l}\text { Pada fungsi kuesioner, sub fungsi kepuasan dosen, apakah anda berhasil } \\
\text { mengaktivasi tombol open ? }\end{array}$ & 1 & 0 \\
\hline Task 34 & $\begin{array}{l}\text { Pada fungsi kuesioner, sub fungsi kepuasan dosen, apakah anda berhasil unduh } \\
\text { template pengisian kepuasan dosen? }\end{array}$ & 1 & 0 \\
\hline Task 35 & $\begin{array}{l}\text { Pada fungsi kuesioner, sub fungsi kepuasan dosen, apakah anda berhasil tambah } \\
\text { soal ? }\end{array}$ & 1 & 0 \\
\hline
\end{tabular}


107 Jurnal Teknologi Informasi Dan Komputer, Volume 5, Nomor 1, Januari 2019

\begin{tabular}{|c|c|c|c|}
\hline \multirow[t]{2}{*}{ Task \# } & \multirow[t]{2}{*}{ Pernyataan } & \multicolumn{2}{|c|}{ Nilai Jawaban } \\
\hline & & Ya & Tidak \\
\hline Task 36 & $\begin{array}{l}\text { Pada fungsi kuesioner, sub fungsi kepuasan dosen, apakah anda berhasil import } \\
\text { data? }\end{array}$ & 1 & 0 \\
\hline Task 37 & $\begin{array}{l}\text { Pada fungsi kuesioner, sub fungsi kepuasan dosen, apakah anda berhasil simpan } \\
\text { data ? }\end{array}$ & 1 & 0 \\
\hline Task 38 & $\begin{array}{l}\text { Pada fungsi proses data, sub fungsi PBM, apakah anda berhasil melihat detail hasil } \\
\text { PBM? }\end{array}$ & 1 & 0 \\
\hline Task 39 & $\begin{array}{l}\text { Pada fungsi proses data, sub fungsi PBM, apakah anda berhasil melihat detail hasil } \\
\text { per dosen? }\end{array}$ & 1 & 0 \\
\hline Task 40 & $\begin{array}{l}\text { Pada fungsi proses data, sub fungsi PBM, apakah anda berhasil menyelesaikan } \\
\text { pencarian dosen? }\end{array}$ & 1 & 0 \\
\hline Task 41 & Pada fungsi proses data, sub fungsi PBM, apakah anda berhasil unduh excel ? & 1 & 0 \\
\hline Task 42 & $\begin{array}{l}\text { Pada fungsi proses data, sub fungsi kepuasan mahasiswa, apakah anda berhasil } \\
\text { unduh hasil kepuasan mahasiswa? }\end{array}$ & 1 & 0 \\
\hline Task 43 & $\begin{array}{l}\text { Pada fungsi proses data, sub fungsi kepuasan dosen, apakah anda berhasil undul hasil } \\
\text { kepuasan dosen? }\end{array}$ & 1 & 0 \\
\hline
\end{tabular}

Tabel 2. Pernyataan Time on Task

\begin{tabular}{|c|c|c|c|c|}
\hline \multirow[t]{2}{*}{ Task \# } & \multirow[t]{2}{*}{ Pernyataan } & \multicolumn{3}{|c|}{ Nilai Jawaban (Menit) } \\
\hline & & $<1$ & 1-3 & $>\mathbf{3}$ \\
\hline Task 1 & Berapa lama waktu yang anda perlukan untuk menyelesaikan proses login? & 1 & 3 & 4 \\
\hline Task 2 & $\begin{array}{l}\text { Pada fungsi kuesioner, sub fungsi PBM, berapa lama waktu yang anda perlukan } \\
\text { untuk menyelesaikan input keterangan? }\end{array}$ & 1 & 3 & 4 \\
\hline Task 3 & $\begin{array}{l}\text { Pada fungsi kuesioner, sub fungsi PBM, berapa lama waktu yang anda perlukan } \\
\text { untuk menyelesaikan input skala likert? }\end{array}$ & 1 & 3 & 4 \\
\hline Task 4 & $\begin{array}{l}\text { Pada fungsi kuesioner, sub fungsi PBM, berapa lama waktu yang anda perlukan } \\
\text { untuk menyelesaikan input tahun ajaran? }\end{array}$ & 1 & 3 & 4 \\
\hline Task 5 & $\begin{array}{l}\text { Pada fungsi kuesioner, sub fungsi PBM, berapa lama waktu yang anda perlukan } \\
\text { untuk menyelesaikan pilih semester? }\end{array}$ & 1 & 3 & 4 \\
\hline Task 6 & $\begin{array}{l}\text { Pada fungsi kuesioner, sub fungsi PBM, berapa lama waktu yang anda perlukan } \\
\text { untuk menyelesaikan input date range? }\end{array}$ & 1 & 3 & 4 \\
\hline Task 7 & $\begin{array}{l}\text { Pada fungsi kuesioner, sub fungsi PBM, berapa lama waktu yang anda perlukan } \\
\text { untuk menyelesaikan proses mengaktivasi tombol SION ? }\end{array}$ & 1 & 3 & 4 \\
\hline Task 8 & $\begin{array}{l}\text { Pada fungsi kuesioner, sub fungsi PBM, berapa lama waktu yang anda perlukan } \\
\text { untuk menyelesaikan proses mengaktivasi tombol elearning? }\end{array}$ & 1 & 3 & 4 \\
\hline Task 9 & $\begin{array}{l}\text { Pada fungsi kuesioner, sub fungsi PBM, berapa lama waktu yang anda perlukan } \\
\text { untuk menyelesaikan proses mengaktivasi tombol open? }\end{array}$ & 1 & 3 & 4 \\
\hline Task 10 & $\begin{array}{l}\text { Pada fungsi kuesioner, sub fungsi PBM, berapa lama waktu yang anda perlukan } \\
\text { untuk menyelesaikan proses unduh template pengisian PBM? }\end{array}$ & 1 & 3 & 4 \\
\hline Task 11 & $\begin{array}{l}\text { Pada fungsi kuesioner, sub fungsi PBM, berapa lama waktu yang anda perlukan } \\
\text { untuk menyelesaikan tambah soal? }\end{array}$ & 1 & 3 & 4 \\
\hline Task 12 & $\begin{array}{l}\text { Pada fungsi kuesioner, sub fungsi PBM, berapa lama waktu yang anda perlukan } \\
\text { untuk menyelesaikan import data? }\end{array}$ & 1 & 3 & 4 \\
\hline Task 13 & $\begin{array}{l}\text { Pada fungsi kuesioner, sub fungsi PBM, berapa lama waktu yang anda perlukan } \\
\text { untuk menyelesaikan simpan data? }\end{array}$ & 1 & 3 & 4 \\
\hline Task 14 & $\begin{array}{l}\text { Pada fungsi kuesioner, sub fungsi kepuasan mahasiswa, berapa lama waktu } \\
\text { yang anda perlukan untuk menyelesaikan input keterangan? }\end{array}$ & 1 & 3 & 4 \\
\hline Task 15 & $\begin{array}{l}\text { Pada fungsi kuesioner, sub fungsi kepuasan mahasiswa, berapa lama waktu } \\
\text { yang anda perlukan untuk menyelesaikan input skala likert? }\end{array}$ & 1 & 3 & 4 \\
\hline Task 16 & $\begin{array}{l}\text { Pada fungsi kuesioner, sub fungsi kepuasan mahasiswa, berapa lama waktu } \\
\text { yang anda perlukan untuk menyelesaikan input tahun ajaran? }\end{array}$ & 1 & 3 & 4 \\
\hline Task 17 & $\begin{array}{l}\text { Pada fungsi kuesioner, sub fungsi kepuasan mahasiswa, berapa lama waktu } \\
\text { yang anda perlukan untuk menyelesaikan pilih semester? }\end{array}$ & 1 & 3 & 4 \\
\hline Task 18 & $\begin{array}{l}\text { Pada fungsi kuesioner, sub fungsi kepuasan mahasiswa, berapa lama waktu } \\
\text { yang anda perlukan untuk menyelesaikan input date range? }\end{array}$ & 1 & 3 & 4 \\
\hline Task 19 & $\begin{array}{l}\text { Pada fungsi kuesioner, sub fungsi kepuasan mahasiswa, berapa lama waktu } \\
\text { yang anda perlukan untuk menyelesaikan proses mengaktivasi tombol SION ? }\end{array}$ & 1 & 3 & 4 \\
\hline Task 20 & $\begin{array}{l}\text { Pada fungsi kuesioner, sub fungsi kepuasan mahasiswa, berapa lama waktu } \\
\text { yang anda perlukan untuk menyelesaikan proses mengaktivasi tombol } \\
\text { elearning? }\end{array}$ & 1 & 3 & 4 \\
\hline Task 21 & $\begin{array}{l}\text { Pada fungsi kuesioner, sub fungsi kepuasan mahasiswa, berapa lama waktu } \\
\text { yang anda perlukan untuk menyelesaikan proses mengaktivasi tombol open ? }\end{array}$ & 1 & 3 & 4 \\
\hline Task 22 & $\begin{array}{l}\text { Pada fungsi kuesioner, sub fungsi kepuasan mahasiswa, berapa lama waktu } \\
\text { yang anda perlukan untuk menyelesaikan unduh template pengisian kepuasan } \\
\text { mahasiswa? }\end{array}$ & 1 & 3 & 4 \\
\hline Task 23 & $\begin{array}{l}\text { Pada fungsi kuesioner, sub fungsi kepuasan mahasiswa, berapa lama waktu } \\
\text { yang anda perlukan untuk menyelesaikan tambah soal? }\end{array}$ & 1 & 3 & 4 \\
\hline Task 24 & $\begin{array}{l}\text { Pada fungsi kuesioner, sub fungsi kepuasan mahasiswa, berapa lama waktu } \\
\text { yang anda perlukan untuk menyelesaikan import data? }\end{array}$ & 1 & 3 & 4 \\
\hline
\end{tabular}


Jayanti, Usability Sistem Penjaminan Mutu STIKOM Bali Menggunakan ... 108

\begin{tabular}{|c|c|c|c|c|}
\hline \multirow[t]{2}{*}{ Task \# } & \multirow[t]{2}{*}{ Pernyataan } & \multicolumn{3}{|c|}{ Nilai Jawaban (Menit) } \\
\hline & & $<1$ & $1-3$ & $>\mathbf{3}$ \\
\hline Task 25 & $\begin{array}{l}\text { Pada fungsi kuesioner, sub fungsi kepuasan mahasiswa, berapa lama waktu } \\
\text { yang anda perlukan untuk menyelesaikan simpan data? }\end{array}$ & 1 & 3 & 4 \\
\hline Task 26 & $\begin{array}{l}\text { Pada fungsi kuesioner, sub fungsi kepuasan dosen, berapa lama waktu yang } \\
\text { anda perlukan untuk menyelesaikan input keterangan? }\end{array}$ & 1 & 3 & 4 \\
\hline Task 27 & $\begin{array}{l}\text { Pada fungsi kuesioner, sub fungsi kepuasan dosen, berapa lama waktu yang } \\
\text { anda perlukan untuk menyelesaikan input skala likert? }\end{array}$ & 1 & 3 & 4 \\
\hline Task 28 & $\begin{array}{l}\text { Pada fungsi kuesioner, sub fungsi kepuasan dosen, berapa lama waktu yang } \\
\text { anda perlukan untuk menyelesaikan input tahun ajaran? }\end{array}$ & 1 & 3 & 4 \\
\hline Task 29 & $\begin{array}{l}\text { Pada fungsi kuesioner, sub fungsi kepuasan dosen, berapa lama waktu yang } \\
\text { anda perlukan untuk menyelesaikan pilih semester? }\end{array}$ & 1 & 3 & 4 \\
\hline Task 30 & $\begin{array}{l}\text { Pada fungsi kuesioner, sub fungsi kepuasan dosen, berapa lama waktu yang } \\
\text { anda perlukan untuk menyelesaikan input date range? }\end{array}$ & 1 & 3 & 4 \\
\hline Task 31 & $\begin{array}{l}\text { Pada fungsi kuesioner, sub fungsi kepuasan dosen, berapa lama waktu yang } \\
\text { anda perlukan untuk menyelesaikan proses mengaktivasi tombol SID ? }\end{array}$ & 1 & 3 & 4 \\
\hline Task 32 & $\begin{array}{l}\text { Pada fungsi kuesioner, sub fungsi kepuasan dosen, berapa lama waktu yang } \\
\text { anda perlukan untuk menyelesaikan proses mengaktivasi tombol elearning? }\end{array}$ & 1 & 3 & 4 \\
\hline Task 33 & $\begin{array}{l}\text { Pada fungsi kuesioner, sub fungsi kepuasan dosen, berapa lama waktu yang } \\
\text { anda perlukan untuk menyelesaikan proses mengaktivasi tombol open ? }\end{array}$ & 1 & 3 & 4 \\
\hline Task 34 & $\begin{array}{l}\text { Pada fungsi kuesioner, sub fungsi kepuasan dosen, berapa lama waktu yang } \\
\text { anda perlukan untuk menyelesaikan unduh template pengisian kepuasan } \\
\text { dosen? }\end{array}$ & 1 & 3 & 4 \\
\hline Task 35 & $\begin{array}{l}\text { Pada fungsi kuesioner, sub fungsi kepuasan dosen, berapa lama waktu yang } \\
\text { anda perlukan untuk menyelesaikan tambah soal ? }\end{array}$ & 1 & 3 & 4 \\
\hline Task 36 & $\begin{array}{l}\text { Pada fungsi kuesioner, sub fungsi kepuasan dosen, berapa lama waktu yang } \\
\text { anda perlukan untuk menyelesaikan import data? }\end{array}$ & 1 & 3 & 4 \\
\hline Task 37 & $\begin{array}{l}\text { Pada fungsi kuesioner, sub fungsi kepuasan dosen, apakah anda berhasil simpan } \\
\text { data? }\end{array}$ & 1 & 3 & 4 \\
\hline Task 38 & $\begin{array}{l}\text { Pada fungsi proses data, sub fungsi PBM, berapa lama waktu yang anda } \\
\text { perlukan untuk menyelesaikan melihat detail hasil PBM ? }\end{array}$ & 1 & 3 & 4 \\
\hline Task 39 & $\begin{array}{l}\text { Pada fungsi proses data, sub fungsi PBM, berapa lama waktu yang anda } \\
\text { perlukan untuk menyelesaikan melihat detail hasil per dosen? }\end{array}$ & 1 & 3 & 4 \\
\hline Task 40 & $\begin{array}{l}\text { Pada fungsi proses data, sub fungsi PBM, berapa lama waktu yang anda } \\
\text { perlukan untuk menyelesaikan pencarian dosen? }\end{array}$ & 1 & 3 & 4 \\
\hline Task 41 & $\begin{array}{l}\text { Pada fungsi proses data, sub fungsi PBM, berapa lama waktu yang anda } \\
\text { perlukan untuk menyelesaikan unduh excel? }\end{array}$ & 1 & 3 & 4 \\
\hline Task 42 & $\begin{array}{l}\text { Pada fungsi proses data, sub fungsi kepuasan mahasiswa, berapa lama waktu } \\
\text { yang anda perlukan untuk menyelesaikan unduh hasil kepuasan mahasiswa ? }\end{array}$ & 1 & 3 & 4 \\
\hline Task 43 & $\begin{array}{l}\text { Pada fungsi proses data, sub fungsi kepuasan dosen, berapa lama waktu yang } \\
\text { anda perlukan untuk menyelesaikan unduh hasil kepuasan dosen ? }\end{array}$ & 1 & 3 & 4 \\
\hline
\end{tabular}

Tabel 3. Pernyataan Usability Rate of System

\begin{tabular}{|c|c|c|c|c|c|}
\hline \multirow{2}{*}{ No } & \multirow{2}{*}{ Pernyataan } & \multicolumn{4}{|c|}{ Skala Likert } \\
\hline & & STS & TS & $\mathbf{S}$ & $\mathbf{S S}$ \\
\hline 1 & Sistem penjaminan mutu STIKOM Bali mudah digunakan & & & & \\
\hline 2 & $\begin{array}{l}\text { Saya dapat menyelesaikan pekerjaan pengelolaan kepuasan pelanggan dengan } \\
\text { cepat menggunakan sistem penjaminan mutu STIKOM Bali }\end{array}$ & & & & \\
\hline 3 & Sistem penjaminan mutu STIKOM Bali nyaman digunakan & & & & \\
\hline 4 & Saya bisa produktif dengan menggunakan sistem penjaminan mutu STIKOM Bali & & & & \\
\hline 5 & Sistem penjaminan mutu STIKOM Bali memberikan pesan kesalahan yang jelas & & & & \\
\hline 6 & $\begin{array}{l}\text { Informasi (panduan, pesan dan dokumentasi lainnya) disediakan pada sistem ini } \\
\text { dengan jelas }\end{array}$ & & & & \\
\hline 7 & Mudah menemukan informasi yang saya butuhkan & & & & \\
\hline 8 & $\begin{array}{l}\text { Informasi yang disediakan sistem penjaminan mutu STIKOM Bali mudah } \\
\text { dipahami }\end{array}$ & & & & \\
\hline 9 & $\begin{array}{l}\text { Desain antarmuka sistem penjaminan mutu STIKOM Bali nyaman untuk } \\
\text { digunakan }\end{array}$ & & & & \\
\hline 10 & Secara keseluruhan saya puas dengan sistem penjaminan mutu STIKOM Bali & & & & \\
\hline
\end{tabular}

\section{HASIL DAN PEMBAHASAN}

Pada hasil dan pembahasan akan dibahas mengenai hasil evaluasi user centered design serta rekomendasi perbaikan sistem informasi penjaminan mutu STIKOM Bali. Berdasarkan hasil analisis usability yang telah ditetapkan,maka evaluasi terhadap tingkat usability sistem informasi penjaminan mutu berdasarkan metode User Centered Design (UCD) menghasilkan data yang digunakan untuk mengambil kesimpulan mengenai tingkat usability sistem.

Berdasarkan data hasil evaluasi responden terhadap sistem informasi 
penjaminan mutu STIKOM Bali melalui kuesioner pernyataan task complete rates, didapat hasil seperti pada Tabel 4.

Tabel 4. Data Hasil Pernyataan Task Complete Rate

\begin{tabular}{|c|c|c|c|c|c|}
\hline $\begin{array}{lll}\text { TASK } & \text { RESPONDEN }\end{array}$ & R1 & R2 & $\mathbf{R 3}$ & R4 & JUMLAH \\
\hline Task 1 & 1 & 1 & 1 & 1 & 4 \\
\hline Task 2 & 1 & 1 & 1 & 1 & 4 \\
\hline Task 3 & $\mathbf{1}$ & $\mathbf{1}$ & 1 & 1 & 4 \\
\hline Task 4 & 1 & $\mathbf{0}$ & $\mathbf{0}$ & 1 & 2 \\
\hline Task 5 & 1 & 1 & 1 & 1 & 4 \\
\hline Task 6 & 1 & 1 & 1 & 1 & 4 \\
\hline Task 7 & 1 & 1 & 1 & 1 & 4 \\
\hline Task 8 & 1 & 1 & 1 & 1 & 4 \\
\hline Task 9 & 1 & 1 & 1 & 1 & 4 \\
\hline Task 10 & 1 & 1 & 1 & 1 & 4 \\
\hline Task 11 & 1 & 1 & 1 & 1 & 4 \\
\hline Task 12 & 1 & 1 & 1 & 1 & 4 \\
\hline Task 13 & 1 & 1 & 1 & 1 & 4 \\
\hline Task 14 & 1 & 1 & 1 & 1 & 4 \\
\hline Task 15 & 1 & 1 & 1 & 1 & 4 \\
\hline Task 16 & 1 & 1 & 1 & 1 & 4 \\
\hline Task 17 & 1 & 1 & 1 & 1 & 4 \\
\hline Task 18 & 1 & 1 & 1 & 1 & 4 \\
\hline Task 19 & 1 & 1 & 1 & 1 & 4 \\
\hline Task 20 & 1 & 1 & 1 & 1 & 4 \\
\hline Task 21 & 1 & 1 & 1 & 1 & 4 \\
\hline Task 22 & 1 & 1 & 1 & 1 & 4 \\
\hline Task 23 & 1 & 1 & 1 & 1 & 4 \\
\hline Task 24 & 1 & 1 & 1 & 1 & 4 \\
\hline Task 25 & 1 & 1 & 1 & 1 & 4 \\
\hline Task 26 & 1 & 1 & 1 & 1 & 4 \\
\hline Task 27 & 1 & 1 & 1 & 1 & 4 \\
\hline Task 28 & 1 & 1 & 1 & 1 & 4 \\
\hline Task 29 & 1 & 1 & 1 & 1 & 4 \\
\hline Task 30 & 1 & 1 & 1 & 1 & 4 \\
\hline Task 31 & 1 & 1 & 1 & 1 & 4 \\
\hline Task 32 & 1 & 1 & 1 & 1 & 4 \\
\hline Task 33 & 1 & 1 & 1 & 1 & 4 \\
\hline Task 34 & 1 & 1 & 1 & 1 & 4 \\
\hline Task 35 & 1 & 1 & 1 & 1 & 4 \\
\hline Task 36 & 1 & 0 & 1 & 1 & 3 \\
\hline Task 37 & 1 & 1 & 1 & 1 & 4 \\
\hline Task 38 & 1 & 1 & 1 & 1 & 4 \\
\hline Task 39 & 1 & 1 & 1 & 1 & 4 \\
\hline Task 40 & 1 & 1 & 1 & 1 & 4 \\
\hline Task 41 & 0 & 1 & 1 & 1 & 3 \\
\hline Task 42 & 1 & 1 & 1 & 1 & 4 \\
\hline Task 43 & 1 & 1 & 1 & 1 & 4 \\
\hline OVERALL (\%) & $97,67 \%$ & $95,35 \%$ & $97,67 \%$ & $100,00 \%$ & $97,67 \%$ \\
\hline
\end{tabular}

Pada data hasil evaluasi task complete rates, dapat diperoleh informasi bahwa :

1. Responden masih mengalami kesulitan dalam menyelesaikan task 4, task 36, dan task 41. Terlihat ada 2 responden yang tidak dapat menyelesaikan task 4, 1 responden yang tidak dapat menyelesaikan task 36 dan 1 responden yang tidak dapat menyelesaikan task 41 .

2. Tingkat keberhasilan responden dalam menyelesaikan task sistem informasi penjaminan mutu STIKOM Bali sebesar $97,67 \%$.

Berdasarkan data hasil evaluasi responden terhadap sistem informasi penjaminan mutu STIKOM Bali melalui kuesioner pernyataan time on task, didapat hasil seperti pada Tabel 5. 
Tabel 5. Data Hasil Pernyataan Time on Task

\begin{tabular}{|c|c|c|c|c|c|c|}
\hline \begin{tabular}{|ll} 
TASK & RESPONDEN \\
\end{tabular} & R1 & $\mathbf{R 2}$ & $\mathbf{R 3}$ & R4 & $\begin{array}{c}\text { JUMLAH } \\
\text { (menit) }\end{array}$ & $\begin{array}{c}\text { RATA-RATA } \\
\text { (menit) }\end{array}$ \\
\hline Task 1 & 1 & 1 & 3 & 1 & 6 & 1,5 \\
\hline Task 2 & 3 & 3 & 1 & 1 & 8 & 2 \\
\hline Task 3 & 1 & 3 & 1 & 1 & 6 & 1,5 \\
\hline Task 4 & 3 & 4 & 4 & 3 & 14 & 3,5 \\
\hline Task 5 & 3 & 3 & 3 & 3 & 12 & 3 \\
\hline Task 6 & 3 & 3 & 3 & 3 & 12 & 3 \\
\hline Task 7 & 1 & 1 & 1 & 1 & 4 & 1 \\
\hline Task 8 & 1 & 1 & 1 & 1 & 4 & 1 \\
\hline Task 9 & 1 & 1 & 1 & 1 & 4 & $\mathbf{1}$ \\
\hline Task 10 & 3 & 1 & 1 & 3 & 8 & 2 \\
\hline Task 11 & 3 & 3 & 1 & 3 & 10 & 2,5 \\
\hline Task 12 & 3 & 1 & 3 & 3 & 10 & 2,5 \\
\hline Task 13 & 3 & 3 & 3 & 1 & 10 & 2,5 \\
\hline Task 14 & 1 & 3 & 1 & 3 & 8 & 2 \\
\hline Task 15 & 3 & 3 & 3 & 3 & 12 & 3 \\
\hline Task 16 & 3 & 1 & 3 & 3 & 10 & 2,5 \\
\hline Task 17 & 3 & 3 & 3 & 1 & 10 & 2,5 \\
\hline Task 18 & 1 & 3 & 3 & 1 & 8 & 2 \\
\hline Task 19 & 1 & 1 & 1 & 1 & 4 & 1 \\
\hline Task 20 & 1 & 1 & 1 & 1 & 4 & 1 \\
\hline Task 21 & 1 & 1 & 1 & 1 & 4 & 1 \\
\hline Task 22 & 3 & 1 & 3 & 3 & 10 & 2,5 \\
\hline Task 23 & 1 & 1 & 3 & 1 & 6 & 1,5 \\
\hline Task 24 & 3 & 1 & 1 & 3 & 8 & 2 \\
\hline Task 25 & 3 & 3 & 1 & 3 & 10 & 2,5 \\
\hline Task 26 & 1 & 3 & 1 & 3 & 8 & 2 \\
\hline Task 27 & 3 & 3 & 3 & 3 & 12 & 3 \\
\hline Task 28 & 3 & 1 & 3 & 1 & 8 & 2 \\
\hline Task 29 & 1 & 3 & 1 & 3 & 8 & 2 \\
\hline Task 30 & 3 & 1 & 3 & 1 & 8 & 2 \\
\hline Task 31 & 1 & 1 & 1 & 1 & 4 & 1 \\
\hline Task 32 & 1 & 1 & 1 & 1 & 4 & 1 \\
\hline Task 33 & 1 & 1 & 1 & 1 & 4 & 1 \\
\hline Task 34 & 3 & 1 & 1 & 3 & 8 & 2 \\
\hline Task 35 & 3 & 1 & 4 & 1 & 9 & 2,25 \\
\hline Task 36 & 3 & 3 & 1 & 3 & 10 & 2,5 \\
\hline Task 37 & 3 & 1 & 4 & 1 & 9 & 2,25 \\
\hline Task 38 & 3 & 3 & 3 & 3 & 12 & 3 \\
\hline Task 39 & 1 & 3 & 1 & 3 & 8 & 2 \\
\hline Task 40 & 1 & 1 & 3 & 1 & 6 & 1,5 \\
\hline Task 41 & 4 & 4 & 4 & 4 & 16 & 4 \\
\hline Task 42 & 4 & 4 & 4 & 4 & 16 & 4 \\
\hline Task 43 & 4 & 4 & 4 & 4 & 16 & 4 \\
\hline \multicolumn{5}{|c|}{ RATA-RATA KESELURUHAN (menit) } & 368 & 92 \\
\hline
\end{tabular}

Pada data hasil evaluasi task complete rates, dapat diperoleh informasi bahwa :

1. Task yang membutuhkan rata-rata waktu penyelesaian yang paling lama adalah task 41, task 42 dan task 43.

2. Waktu rata-rata paling lama yang diperlukan responden untuk menyelesaikan task 41, task 42 dan task 43 adalah sebesar 4 menit.

3. Waktu rata-rata yang diperlukan responden untuk menyelesaikan seluruh task adalah sebesar 92 menit. 
111 Jurnal Teknologi Informasi Dan Komputer, Volume 5, Nomor 1, Januari 2019

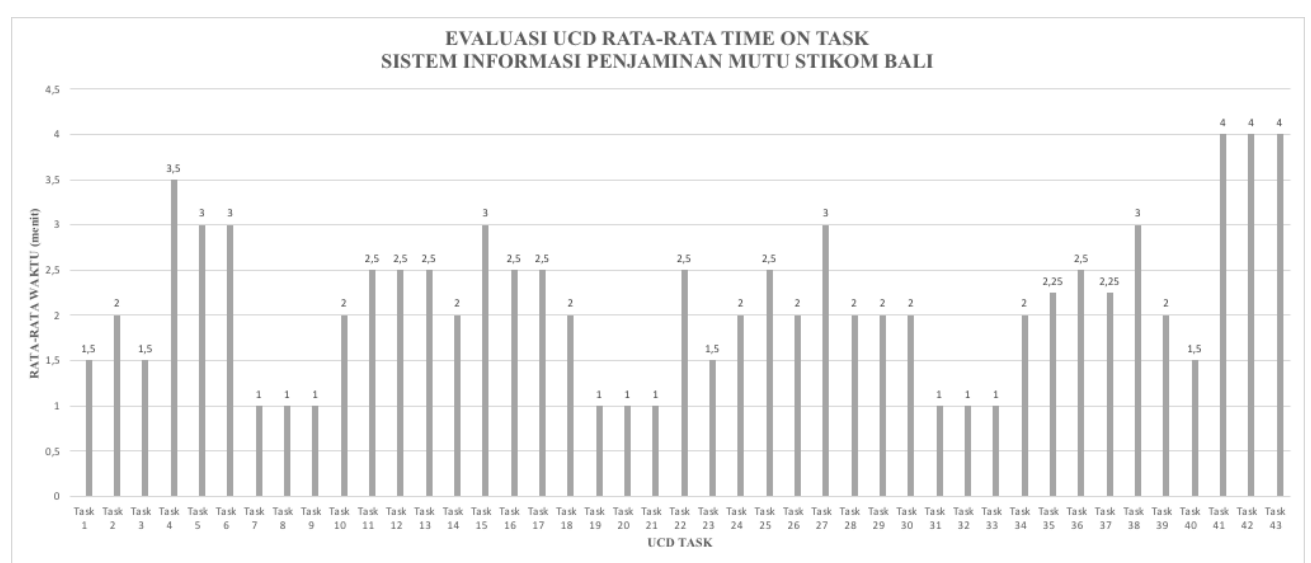

Gambar 1.Grafik Time on Task Sistem Informasi Penjaminan Mutu

Berdasarkan data hasil evaluasi responden terhadap sistem informasi penjaminan mutu STIKOM Bali melalui kuesioner pernyataan

usability rate of system, didapat hasil seperti pada Tabel 6 dan Tabel 7.

Tabel 6. Data Hasil Pernyataan Usability Rate of System

\begin{tabular}{|c|c|c|c|c|}
\hline RESPONDEN & R1 & R2 & R3 & R4 \\
\hline Task 1 & & & & \\
\hline Task 2 & 3 & 4 & 3 & 3 \\
\hline Task 3 & 3 & 3 & 4 & 3 \\
\hline Task 4 & 3 & 3 & 3 & 3 \\
\hline Task 5 & 4 & 4 & 4 & 3 \\
\hline Task 6 & 4 & 4 & 4 & 4 \\
\hline Task 7 & 4 & 4 & 4 & 4 \\
\hline Task 8 & 4 & 4 & 4 & 4 \\
\hline Task 9 & 3 & 3 & 3 & 4 \\
\hline Task 10 & 4 & 4 & 4 & 4 \\
\hline
\end{tabular}

Tabel 7. Data Hasil Usability Rate of System

\begin{tabular}{|c|c|c|c|}
\hline ALTERNATIF JAWABAN & JUMLAH & PRESENTASE & TOTAL SKOR \\
\hline Sangat Tidak Setuju (STS) & 0 & $0 \%$ & 0 \\
\hline Tidak Setuju (TS) & 0 & $0 \%$ & 0 \\
\hline Setuju (S) & 18 & $45 \%$ & 54 \\
\hline Sangat Setuju (SS) & 22 & $55 \%$ & $\mathbf{1 4 2}$ \\
\hline \multicolumn{2}{|c|}{ SKOR KESELURUHAN } & $\mathbf{8 8 , 7 5 \%}$ \\
\hline
\end{tabular}

Pada data hasil evaluasi usability rate of system, dapat diperoleh informasi bahwa tingkat usability yang dirasakan responden saat menggunakan sistem informasi penjaminan mutu adalah $88,75 \%$.

Berdasarkan keberhasilan responden dalam menyelesaikan task sistem informasi penjaminan mutu STIKOM Bali, maka rekomendasi perbaikan yang dapat diberikan pada sistem informasi penjaminan mutu STIKOM Bali adalah :
1. Perbaikan tipe data pada field tahun ajaran yang disesuaikan dengan kebutuhan pengguna.

2. Sistem informasi penjaminan mutu STIKOM Bali perlu dilengkapi dengan informasi/ petunjuk penggunaan sistem. 


\section{SIMPULAN}

Dalam implementasi metode User Centered Design (UCD) pada sistem informasi penjaminan mutu STIKOM Bali telah ditetapkan tiga jenis pernyataan yaitu Task Complete Rate, Time on Task, dan Usability Rate of System. Tingkat keberhasilan responden dalam menyelesaikan task sistem informasi penjaminan mutu STIKOM Bali sebesar $97,67 \%$. Waktu rata-rata yang diperlukan responden untuk menyelesaikan seluruh task adalah sebesar 92 menit. Tingkat usability yang dirasakan responden saat menggunakan sistem informasi penjaminan mutu adalah $88,75 \%$.

\section{DAFTAR PUSTAKA}

[1] Dedi RR, Pengukuran Usability Sistem Menggunakan Use Questionnaire pada Aplikasi Android, Jurnal Sistem Informasi (JSI), Vol. 6, No. 1, Universitas Sriwijaya., 2014

[2] Yani N, Susy KS, Irman H, Husnul K, Pengujian Usability untuk Meningkatkan Antarmuka Aplikasi Mobile, Jurnal Ilmu Komputer AgriInformatika, Vol. 2, No. 2, Institut Pertanian Bogor, 2013

[3] R. Sari, E. Utami, A. Amborowati, Rancangan Lowongan Kerja Online menggunakan Metode User Centered Design (Studi Kasus : Business Placement Center STMIK Amiko Yogyakarta), Creative Information Tecnology, 3, 62-73, 2015

[4] Rosyidah U., Kusrini, Henderi, 2018. "Evaluasi Usability pada Aplikasi Simpatika Direktorat Jenderal Pendidikan Islam Kementerian Agama", Prosiding Seminar Nasional Sistem Informasi dan Teknologi Informasi, ISSN : 2621 - 0428, STMIK Pontianak.

[5] Dumas, Redish,,et al., Apractical guide to Usability Testing, John Wiley \& Sons, 1999

[6] ISO 9241-11, Guidance on Usability, International Organization for Standardization, 1998

[7] Unicom Codelabs, User Centered Design, Tanggal akses 20 April 2018, url : https://medium.com/codelabsunikom/user-centered-designee25536850b7

[8] Jayanti NKDA, 2018."Analisis Usability Sistem Penjaminan Mutu STIKOM Bali menggunakan Metode User Centered Design", Prosiding Seminar Nasional Telekomunikasi dan Informatika, ISSN : 2503-2844, Sekolah Tinggi Teknologi Bandung. 